\title{
Swinging Doors:
}

\section{An Autoethnographic Look at the Challenges \\ Faced by Previously Incarcerated People \\ in the USA and Australia \\ Lukas Carey, Adam Grant and Scott Tompkins}

\section{INTRODUCTION}

In order to provide context to this piece of work, it is important to provide some information on the authors. Each of the three authors has been previously incarcerated in either USA (Michigan) or Australia (Victoria) and brings their individual lived experiences to this piece. Their terms of imprisonment vary, as do the security level of the prisons in which they were incarcerated. Additionally, the severity of offences to which they were charged also vary immensely, bringing a wide spread of experiences and context to this piece. The experiences of the authors are individual but have been brought together into this piece to indicate the similarities that occur between incarceration in the USA and Australia.

The USA and Australia have very different criminal justice and penal systems. However, the lived experiences of those inside the two countries' systems are very similar, in many instances. Collateral consequences exist on opposite sides of the globe. Consequences that are counterproductive to the claimed goals of the criminal justice system also occur in both countries.

Obvious experiential differences exist and are strongly linked to a set of individual variables. Some of these variables include the length of sentence given, the type of prison where imprisonment was served, the security level of the prison where time was served, the state/territory in which time was served, where the person was housed (e.g. unit, cell, isolation), where they were released and the state in which release occurs (Wilson and Reuss, 2000). These differences will be explored further in a more extensive study being designed to consider a larger cohort across Australia and the USA.

The challenges faced by the large majority of people returning to the community after period(s) of incarceration are often unique and exist for several reasons. Frequently, the person returning to the community has incurred a measure of institutionalization, after having accommodation, food, etc. provided for them in a controlled environment for a long period of time (Nardini, 1966; Binswanger et al., 2009). Another of these challenges occurs due to the potential change in incarcerated peoples mental 
and emotional state as a product of the trauma and emotional stress of incarceration (Johnson, 1989; Sharac et al., 2010). These common changes make the released person view things differently due to the conditioning that the pressured rituals of incarceration create, day-to-day.

Taking these changes to the incarcerated person and/or their families into consideration, a set of structural challenges exist that seem to be common place among previously incarcerated people in the USA and Australia.

The list of these structural challenges is extensive but using simple subheadings and the lived experiences of three previously incarcerated men, two in the US and one in Australia, this paper looks at the real-life challenges faced upon their return home. These challenges are real, not theoretical and the happenings come directly from the experiences of the three authors. It is hoped that others, who have shared or currently share these experiences, may gain some form of solace from the fact that others have 'felt what they feel' or have 'experienced what they have experienced'. It is hoped that this type of autoethnographic work will highlight the challenges faced across the globe and that these challenges are not insurmountable.

Behind these lived experiences, a set of political and racial variables exist in both the USA and Australia that also have a huge influence over incarceration in those countries. Ideas relating to colonization, skin colour, political beliefs in varying jurisdictions and the biases formed over decades of cultural stereotype development, all influence incarceration in the USA, Australia and many other countries (Wolfe, 1999). These complexities form the basis of extensive research and although acknowledged in this paper, will be explored in further work on the topic.

\section{THE REVOLVING DOOR}

The swinging door is a reality for many but for the large part, the door looks more like a revolving one. This is the revolving door that many formerly incarcerated men and women spend much of their post-incarcerated time trying to avoid - not wanting to be sucked back into the carceral industrial complex (Freeman, 2003; Levesque, 2020). The dance of avoiding recidivism and violating parole conditions is strenuous and taxing and can negatively influence the pursuit of remaining 'on the straight and narrow'. With the number of people incarcerated in the US and Australia constantly increasing, the number of people under some form of community 
supervision order or parole requirement, the reach of the carceral system expands exponentially (Glaze and Bonczar, 2011; Grubb, 2020; KangBrown et al., 2020).

In three short decades, the US prison system underwent considerable and largely unpredicted demographic shifts. The US prison population expanded greatly when it was previously declining, increasing from just over 400,000 prisoners in 1970 to well over 2 million by the turn of the 20th century (Hartney, 2006; Sampson and Loeffler, 2010; Kang-Brown et al., 2020). At the same time the prison system 'blackened', demographically shifting from two-thirds White in 1970 to two-thirds non-White people of color, nearly half of which were Black men, by the year 2000 (Wacquant, 2002a, 2002b).

Over two-thirds of all prisoners live at or below half of the US poverty line (Wacquant, 2009a, 2009b) and prisoners in most states come from the most populous, racially segregated, and disadvantaged communities (Bobo and Thompson, 2010; Sampson and Loeffler, 2010). Adding to these complications, most released prisoners in the US are re-arrested in just under three years (Wilson, 2019). The bulk of these are re-arrested while still on parole and community supervision orders (Grubb, 2020; KangBrown et al., 2020).

Australia continues to also experience a growth in the amount of people being incarcerated (Australian Bureau of Statistics, 2018a, 2018b, 2020). Prisoner receptions increased by an average of $9 \%$ per month during 2020 with more than 200 people incarcerated daily across the country (ABS, 2020 ). Within this growing number, more than $80 \%$ of prison receptions identify as male and more than $10 \%$ identify as female, with the remainder identifying as a gender alternate to those (ABS, 2020).

The challenges faced by the authors who served periods of incarceration in the USA and Australia are varied, but are outlined throughout this paper, using lived experience to provide context and points for consideration. The challenges are listed below.

\section{EDUCATION}

The ability to gain access to education after incarceration, is often limited and that was in fact the case for author Lukas in a couple of ways. The first, and probably the more challenging initially, was the ability to be able to afford training to return to the workplace. 
As a trained teacher in Australia, who has a white-collar criminal record, the ability to work in government settings is now severely influenced. However, the ability to return to education as a trainer required more training, that is training I could not afford or gain access to. Many of the people I engage with on a daily basis, along with research, shows that this structural inequity issue is one that many people who have the lived experience of previous incarceration deal with (Wilson and Reuss, 2000; Harding et al., 2014). The inability for many people who may wish to change their lives, or the lives of their families, through additional education has been shown to almost set them up to fail post-release (Renton, 2013). Without the drive and my own education gained prior to incarceration, I would have been set up to fail, as my ability to gain education was limited due to finances, access, and the policies of some educational facilities.

Incarceration is taxing and financially expensive for all family members involved. These expenses vary from travel and related costs to visit family members, paying bills on a potentially changed and diminished household income, changed accommodation costs with reduction of household income, and the emotional aspect of missing a family member. My (Lukas) own lived experience incorporates all of these, and the reality was that the ability to ask any family member for $\$ 1000$ to complete my trainer qualifications in order to gain employment was simply never going to happen. What other options did I have? Government handouts? Benefits?

Being on unemployment benefits in Australia is definitely not a way to get rich and the low amount of money you get makes it challenging to live in any functional way. When you need to start putting money straight back into a household you just left to pay bills and feed your family, the chance to find that money to complete the trainer certification was not easy but was essential to avoid a return to the prison cycle (Uggen, 2000; Western, Kling, and Weiman, 2001).

Without the ability to afford the trainer qualification, I (Lukas) commenced the search online for employment. The interaction with online employment sites continued for months with the idea of being a trainer slotted into the background. I was offered an income stream by a person I met while incarcerated (which I quickly declined), but the hunt was a mentally challenging one. I was at the end of possibilities and asked my employment case manager (given to all people receiving unemployment benefits in Australia) for advice. The advice surprised me and was marginally helpful with the case manager seeing me as an easy opportunity to return someone 
to the workforce. They offered to pay for half of the qualification if I could find the rest, a glimmer of hope.

It took some pleading with my brother and some scraping and scrimping by my wife and I, that the rest was found and I (Lukas) was able to gain access to the course I needed to get my working life back on track. The opportunity was now there for me, but for those people returning without family support or being lucky enough to have an employment consultant who saw an opportunity, the opportunities are often dire (Brown, 2015; Bushway et al., 2007; Scott, 2016). It is essential that assistance packages or an assistance fund be offered to previously incarcerated people upon their return to the community. This package should be tailored to meet the individual needs of the person and their families in order to minimize reoffending and possible recidivism. It has been shown that education should and could play a major role in this and I know from my own experiences, this may have been the case (Steurer and Smith, 2003; Harding et al., 2014; Cherney and Fitzgerald, 2016; Galeshi and Bolin, 2019). This assistance fund would allow for career-changing educational opportunities to be explored further. An employment fund is currently allocated to job providers in Australia for use on smaller, generalized issues that reduce the barriers to employment in many entry-level positions. The revised package would be substantially different from the job provider employment fund, as it would be individualized for the previously incarcerated person.

\section{GAINING INSURANCE / CREDIT}

A fundamental, yet hugely challenging situation faced by many when they return from incarceration in Australia, especially those with white-collar offences, is the ability to gain access to insurance and also credit (Goulding and Brown, 2007).

Many previously incarcerated people may be lucky enough to already have a house, caravan, or unit that requires insurance. Many do not, but may own a car or utility vehicle, that requires insurance. With many convictions, in Australia, the opportunity to gain insurance is only available after a specified and extensive period of time. The large majority of Australian insurance providers require a five-year period after a person is charged with a fraud-related charge to gain insurance to cover physical items. I understand the mitigation of risk, but I must ask the question as to 
how it can halt the return to normality or the return to the community of someone trying to recommence their lives and the lives of their families. A person with a house, who cannot insure it, a family with a car that they cannot insure, or a previously incarcerated tradesperson who cannot get insurance for their own tools and work vehicle as they try to rebuild their lives as the result of a risk algorithm inhibiting their ability to return to their lives prior to incarceration (Renton, 2013; Grgić-Hlača et al., 2018; Williams et al., 2018).

The challenges are even greater for those that do not own any form of infrastructure such as a house, office or machinery, yet want to try and rebuild their own lives and the lives of their families. In order for a large majority of Australians to gain access to the property market, they require access to the credit market. Having a criminal record, especially a fraud-related offence, makes accessing the credit many need to recommence their lives nearly impossible. Banks, credit unions and loan brokers in Australia, similar to insurance agencies, use complex algorithms to measure the mitigated risk of providing credit to an individual. The risk of providing credit to people with a criminal record is seen as a risk that the large majority of financial institutions are not willing to take, especially if these criminal records are fraud related (Kashyap et al., 1992; Bar-Gill and Warren, 2008). This restrictive practice leaves many individuals and their families without the opportunity to continue their lives in a productive manner.

Personally, I (Lukas) have a growing family and I made a mistake in my past. However, does that mean that when I return to the community, start working full-time, and am giving back to the community, that I cannot be able to access credit to build or buy a house for my family? Again the use of this singular formula and risk assessment algorithm negates the opportunity for many with criminal records to gain access to credit.

This credit conundrum then goes further and influences not only the livelihood of those that have been previously incarcerated, but also the ability of many to return to or further develop their own business ideas. How could a self-employed builder, returning from incarceration, return to his/her business and try and expand, without access to credit or insurance? In the eyes of credit and insurance providers, the risk is inherent, however, in reality, is it? Maybe a look at the practices of credit and insurance companies in relation to their interactions with previously incarcerated people may be in order. This will help returning citizens to recommence 
their lives positively and may even assist in reducing recidivism and the return to crime.

\section{MEDIA REPORTING / ONLINE HISTORY}

The role of the media and the way it reports on crime, punishment, and offenders plays a major role in the way previously incarcerated people can see themselves, and are seen by others, upon return to their communities (Sumner and Sutton, 1992; Milivojevic and McGovern, 2014). The current worldwide media environment and the focus on fake news has and continues to question the effectiveness, honesty, and role of the media and some of the journalists that work in the industry (Wang, 2017). The term 'fake news' is a term that has reached famed proportions across the entire world, making some in the media reconsider their ethical and reporting practices (Conroy et al., 2015).

Media plays an important role in the reporting of crime and justice in the community; however, it has been shown that the way in which that reporting is framed and takes place, can have huge effects on the people in those reports (Hinds, 2005; Milivojevic and McGovern, 2014; Cohn et al., 2020). It has been shown that not only the perpetrators of crime but also the victims can be painted negatively through media coverage, with the effects being long term both mentally, emotionally and has been shown to limit future employment opportunities (Sumner and Sutton, 1992; Hinds, 2005; Grosholz and Kubrin, 2007).

Within the Australian context newspapers and media outlets, as well as their journalists, are fighting to remain relevant in the age of social media, and this has led to the lines of ethical journalism being blurred somewhat (Rao and Wasserman, 2007; Christians et al., 2008; Gordon et al., 2011). The 24-hour news cycle, and the need to fill it, has changed the art of journalism forever and of the many victims of this change in delivery style are both the victims of and perpetrators of crime (Sumner and Sutton, 1992; Cook et al., 1999). The reporting of crime, and the people involved, is occurring without the checks and balances that media received in previous years and decades (Deuze, 2017; Tiffen, 2010; Wright and Doyle, 2019). The time does not exist and the ability to access the sources that were previously used also does not exist. This opens the door to an element of 'lazy' journalism where sources such as social media or other online sources are used as primary, 
resulting in factual errors and subjective attitudes being passed on to readers (Deuze, 2017).

Often a result of these 'errors' or emotive or subjective reporting practices is the person that has undertaken a criminal offence. It could be suggested that many journalists 'forget' that their words remain forever and if the opinion or direction of the story is slighted in one way, they present a misleading headline or bury the lead in a story, the wrong or incorrect message could be presented to the reader. These headlines and stories remain listed on the internet and in online libraries, never letting the offender move on from their previous actions, even after serving their time and repaying their debt to society.

Lived experience and the experiences of many others both in the USA and Australia have shown that a large majority of people returning from incarceration attempt to turn their lives around once they have returned home (Naylor, 2011). The large majority accepts and owns their own mistakes and tries to return to meaningful employment, but have the stigma and ongoing existence of criminal record and actions on the internet and media holding them back and making others judge the type of person they are according to their past actions, not the person they actually are (Naylor, 2011; Grier and Bright, 2019; Ryan et al., 2020).

A lot of employment opportunities require a criminal record check, and in the cases of many states in Australia, after a certain amount of time any convictions against people become spent and disappear off these records (Naylor, 2011; Paterson and Naylor, 2011). However, the media reports of a crime or offence remain online and available to anyone. This loophole realistically allows for people's spent offences to still be sourced via media reports online, often negatively influencing the employment opportunities of those who have previously offended. This is never more obvious than if the initial media reports were incorrect, biased, or victimizing in the first place, this type of media is an ongoing challenge faced by many returning home after incarceration (Hinds, 2005; Tiffen, 2010; Wang, 2017).

To remove or manage this challenge, a review of media practices in the reporting of crime is desperately needed. A discussion or review of the time an article remains online on a media site is key. When a conviction is spent and removed from the criminal record of an individual, it is suggested that the online media reporting of the crime be removed. Additionally, the ongoing re-referring of a previous crime in the media when a similar crime 
is committed by another person continues to restrict them from moving on to the next chapter of their life. However, it could be argued that if a more selective and ethical reporting standard of crime, with a human focus, took place in the first place, then some of these barriers wouldn't be faced at all.

\section{HOUSING}

The ability to source and gain access to reliable and safe housing upon release is a major challenge for many people returning to the community post-incarceration (Evans et al., 2019; Griffith, 2019; Hatami, 2019; Halushka, 2020). Shortly before my (Adam) release from a US prison, my grandmother and my father-in-law passed away. This left my mother-inlaw, at nearly 83 years old, as the eldest member of our family, and the one who required our closest attention. This, coupled with a vacancy in the apartment above her, prompted the move by my partner and I to attempt to move closer to her so that we could better care for her, as needed.

Many housing and accommodation applications in the USA require reference checks, credit checks, and previous employment checks (Leasure, 2019; Simes, 2019; Jacobs and Gottlieb, 2020). My previous crimes led me (Adam) to serve a lengthy period of incarceration and I had only been released two months prior. Therefore, I had no credit history or recent references. My fiancée and I decided it best that she be the leasee and that I simply be an authorized occupant. She applied accordingly and within the week she heard back from the property manager, "Congratulations, you got it". Even though I was not a leasee, and we had already told the property manager that I had a criminal record, she said, "We just need Adam to fill out some paperwork and we'll be good". Prior to this, we already informed her that I had a criminal record and that my most recent conviction was for a bank robbery in 1993. Still, I filled out the requested paperwork and the next day we were contacted and told we could not move into the building. This type of discrimination is common to previously incarcerated people and in this, instance their partner (Evans et al., 2019). The requirements around gaining housing or accommodation are not designed with previously incarcerated people in mind and the checks and balances required make it near impossible for many (Hatami, 2019; Leasure, 2019; Jacobs and Gottlieb, 2020). 
Let me clarify, this denial of housing was purely a result of my criminal history. We informed them before the fact that I had a US criminal record, ensured the lease was in my fiancée's name, and offered to pay 6 months of rent in advance. The person looking after the registration process made it clear that money and financial security were not the issues, which is a common theme shared by many across both the USA and Australia (Hatami, 2019; Leasure, 2019; Simes, 2019; Sirois, 2019). There was nothing that would make them reconsider. The 'scarlet letter' of a criminal conviction was enough to override an application that was already approved, the security of 6 months' rent in advance, and the fact that we may need to move my mother-in-law to another complex; all this even though the conviction was over 27 years old!

This continues a similar theme of checks and balances versus the reality of lived experience, as I experienced in the USA. It is understandable that the considerations of businesses to ensure they hire or rent their properties to 'trusted' people are appreciated, but remains open to be challenged as it actively discriminates against people with criminal convictions, regardless of their severity or recency (Evans et al., 2019; Griffith, 2019; Hatami, 2019; Leasure, 2019; Simes, 2019; Sirois, 2019; Halushka, 2020; Jacobs and Gottlieb, 2020). A revision of the practices of real estate businesses, a review as to the roles of support agencies for those returning to the community, and also the systemic discrimination of previously incarcerated people needs immediate and sustained attention on both macro and micro levels.

\section{THE BACKLASH OVER "BAN THE BOX"}

The USA is currently in the midst of an active campaign called 'Ban the Box' (Doleac, 2019; Craigie, 2020; Doleac and Hansen, 2020). This campaign is designed to challenge the existence of the tick box option that appears in a large number of employment applications asking about a person's previous convictions (Doleac, 2019). This attempt to remove the question, "have you been convicted of a felony" from employment applications has enjoyed some success in many localities (Doleac, 2019). Theoretically, this was a brilliant remedy to the prescreening of applications that often took place with the previous system. Had that (banning the box) been the end of it, 
one of the collateral consequences of a criminal conviction - stigma - may have been largely mitigated (Daly, 2020; Sherrard, 2020). However, there seems to be collateral consequences associated with the implementation of this new policy as well, with people continuing to serve a period of limited employment, even after being released and having returned to society. Something that often happens when policies are addressed but the underlying biases and stigmas are not (Doleac, 2019; Doleac and Hansen, 2020).

As is common for many incarcerated people in the USA, I had little problem obtaining an interview after my release from prison. Within a month of applying for several positions, I had participated in somewhere between 10 and 15 interviews, all but one of which offered me the position. Unfortunately, the next step in the process was a criminal background check even though I had been forthright and transparent about my criminal history.

The lived experiences of many across the USA suggest this is not an uncommon practice, with the decision to offer employment not being based on the interview, prior work history, education, or locally considered factors (Jensen and Giegold, 1976; Flake, 2015). Whereas local managers make decisions based upon recorded facts and personal impressions, corporate decisions are based solely on an impersonal formula. This formula overemphasizes past indiscretions and pays absolutely no attention to the lessons learned from that past (Byron, 1970; Fahey et al., 2006; Flake, 2015). In my case, as a 49-year-old man, I (Adam) was being denied the opportunities for employment because of a decision I made at 22 years old, and notwithstanding the lessons learned in the proceeding 27 years. This general denial is a common occurrence amongst previously incarcerated people (Jensen and Giegold, 1976; Fahey et al., 2006; Pogrebi et al., 2014).

The intentions of the Ban-the-Box movement are and have been well intentioned. However, it is not the box that needs to be eliminated but the stigma of a criminal conviction. We cannot continue to merely treat the symptoms if we are not going to address the actual disease. It may not be realistic to believe that we will change the minds of many, concerning returning citizens, but, we can make it clear that the proliferation of such prejudice cannot be tolerated (Harding, 2003; Craigie, 2020). It will take time, consistency, and stamina to turn this mentality around. It won't happen overnight, which makes it all the more important that we start the process, in earnest, now. As with any movement, it will take a courageous few to blaze the trail for others. 


\section{EMPLOYMENT}

Employment is an ongoing challenge for the large majority of previously incarcerated people in the USA (Jensen and Giegold, 1976; Harding, 2003). In some instances, lived experience (Van Manen, 1990; Reid et al., 2005) can be positive when it comes to employment opportunities, the problem is that these opportunities are often limited. Employed as a Certified Peer Recovery Coach (CPRC) in the USA, I (Adam) am trained to use my life experience and scientific methods to help those in their recovery from various addictions. It is my lived experience that creates the initial qualification to become a CPRC. My lived experience opened the doors of employment for me to reach some people that more clinical experts may be unable to. It is also my lived experience that provides the credibility that I enjoy in my place of employment. Yet, it is also my lived experience, at least one part of it, that has prevented me from plying my trade in certain venues - my criminal history.

My life has been transformed in ways that are beyond expression, making me now a very employable individual with something to offer. Previously, I was a person who believed he had no worth. Life has shown me that I have something to offer and that I am a beneficial presence. My life and employment is now one of helping others. I have a penance that cannot be fulfilled simply by working in a warehouse somewhere, unlike many others who return to the community after periods of incarceration. Despite limited vocational experience on my part this is a common theme with people who have held positions of responsibility before incarceration (Byron, 1970; Harding, 2003; Flake, 2015). I am meant to use my past crimes, mistakes, and transgressions to the benefit of others. To do so, to my fullest potential, I need others to open the door and let me into certain 'rooms'? This is a major challenge faced by people returning to the community when they recommence the search for employment and is a barrier that remains prevalent today (Fletcher, 2001; Harding, 2003; Blumstein and Nakamura, 2009; Ross et al., 2011).

Common sense tells us what Eleanor Roosevelt so eloquently encapsulated when she stated, "Learn from the mistakes of others. You cannot live long enough to make them all yourself” (Sutton, 2010). Whether she knew she would or not, Eleanor Roosevelt started to make the argument for the current lived experience movement and to some extent 
the employment of people with lived experience. Yet, many charged with making decisions that affect a large proportion of the community, still see us for our mistakes as something less than valuable (Harding, 2003; Jones, 2003; Fahey et al., 2006; Flake, 2015), negatively influencing our ability to find and hold meaningful employment. Instead of using our mistakes to benefit those who have not traveled as far down the same path, doors remain closed, and people on both sides of those doors are denied mutual benefit. These challenges, although expressed by me as an author in the USA, are shared and experienced by previously incarcerated people in other areas such as Australia, the UK and Europe. The commonality of this across many countries is an area requiring ongoing and further exploration and study. Yet again, a common thread for previously incarcerated people in both the USA and Australia (Uggen, 2000; Western et al., 2001; Spier, 2002; Jones, 2003; Pager, 2003).

Regardless of what common sense dictates, current practice, policy, and protocols deny countless individuals the benefit of this experiential knowledge (Albright and Denq, 1996; Austin and Hardyman, 2004; Blumstein and Nakamura, 2009). Notwithstanding the wisdom contained in Mrs. Roosevelt's statement, the 'powers that be' continue to enable the propagation of ignorance when the necessary teachers are readily available. This benefits no one and is counterproductive to claimed goals of both the criminal justice system and higher education. Denying access to these unique resources extends the victimization from the initial crimes beyond necessity and to society as a whole.

\section{FINES / COST}

Successful reentry into society can prove difficult, as there are many barriers, including limited access to mental health treatment and housing options, financial stressors, and a lack of support from loved ones (Berger et al., 2013). As financial obligations and requirements can be key to post-prison success, the myriad of debts and responsibilities that returned citizens in the USA could incur are a very efficient lubricant for the swinging/revolving door (Bruns, 2020). Women and men who have re-entered society, with untreated substance abuse and mental/physical issues, combined with the stresses and dysfunction that the very act of re-entering our techno-centric 
culture have an ever increasingly difficult time surviving (Hamilton and Belenko, 2019; Mowen et al., 2019).

This vicious and insidious cycle is often spawned by the very financial impacts that are imposed by the corrections, legal, judicial, and social service systems that are supposed to be benefiting them (Mielitz and Marcum, 2020). The issues that encourage recidivism include unemployment, substance abuse, mental and physical health issues, lack of housing, and parole/probation violations (Hester, 2019; Link et al., 2019; Coupland and Olver, 2020; Latessa et al., 2020). It is hard not to conjecture that the incredibly high prison and jail populations in the USA are guaranteed and supplied by the failure in systems designed to "help".

As my colleagues (Lukas and Adam) have detailed in their sections of this paper, housing, employment, and education are key aspects of life that are encountered by formerly incarcerated men and women upon re-entry into their communities, myself (Scott) included (Harding et al., 2014). Most often, expenses incurred for essential living are challenging enough (Keene et al., 2018). When you enter into parole and or probation upon your release, you often incur a myriad of additional expenses, imposed by local jurisdictions, courts, and in the case of the US, states in which you reside (Malin, 2007).

These additional expenses include costs, fines, restitution, and surcharges that are imposed by the courts and other criminal justice agencies on persons accused and/or convicted of crimes. Each monetary sanction has a unique purpose (Harris, 2016). Costs are payments to reimburse the state and local jurisdictions for the costs of the criminal justice procedure. Fines are monetary penalties that can be either mandatory or by the discretion of the judge and are imposed to act as punishment for committing a crime (Harris et al., 2011). Restitution is a court-ordered payment some offenders must pay to their victim(s) to compensate them for their loss and/or injury.

Lastly, surcharges are add-on amounts implemented to generate revenue in the USA for goals not necessarily related to the criminal justice procedure. The principal argument made by the criminal justice system is that courtordered monetary sanctions act as rehabilitation, retribution, and a deterrent to prevent recidivism (Byrne et al., 1992; Tostlebe, 2017). The restitution component of monetary sanctions is proposed to work as a function of restoration, but the effectiveness of this approach is still the topic of rigorous 
debate (Ervin and Schneider, 1990; Schneider and Ervin, 1990). It has been suggested however, that monetary sanctions do have some punishment value for offenders but often do not match the circumstances of the accused and often the crime that has been committed (Ruback, 2011).

Despite the intent or methodology of the entities that impose the monetary punishments on returning citizens, the results are often catastrophic (Harris, 2016; Tostlebe, 2017). When factoring in the economic conditions and circumstances in minority communities, the monetary constraints placed on formerly incarcerated people can be a potent catalyst to propelling the revolving door (Tostlebe, 2017). Most prisoners are released into some form of community supervision. The organizations tasked with meeting former prisoners' service needs are overwhelmingly concentrated within the neighborhoods prisoners come from (Latessa et al., 2020). As a result, prisoners are arrested, returned to, and rehabilitated all within the disadvantaged neighborhoods they come from.

For example, one of the costs that judicial entities can impose is having returnees pay for their incarceration. Sometimes, this is for local entities only, but at other times it can be for state prison. In my case, I (Scott) was charged $\$ 37,000$ for eighteen months of incarceration at the state level. Given that I am a white male, of retirement age, and privileged in education and employment prospects, my hardship is so much less than the majority of people coming home. Nonetheless, it is my hardship and my onus to deal with. I can make my payments, with my part-time work in my privileged, majority-white community, which is definitely not the norm. If I am a minority, possibly living in poverty, with all of the marks and strikes stacked against me by my circumstance, the speed and severity of the revolving door swinging around to whack me back into crime are often overwhelming. This is where and when recidivism can and does rear its ugly head.

\section{ELECTRONIC MONITORING}

Another area of extreme consequence to myself (Scott) and thousands of other newly released prisoners, especially in the USA, is part of the parole and probation system. This is the dreaded electronic monitoring (EM), GPS tracking device, or tether. The ankle/wrist bracelet (depending upon your place of incarceration) becomes part of your anatomy before you are allowed to exit the gates of the prison or jail you are being released from, 
depending upon your release requirements. My own lived experience in the USA is extensive in this instance as I wore one of these electronic devices for all 730 days of my parole.

The state of Michigan 'allowed' me to pay $\$ 13$ per day for the privilege of wearing such a unique fashion accessory. Yes, doing the math, that is $\$ 9,490$ for the two-year parole period. The financial burden of wearing these devices can be devastating if you are struggling to make ends meet (Causey, 2013; Bartels and Martinovic, 2017). Additionally, GPS units are finicky, need constant care and charging, and often require adherence to strict boundaries set up by parole officers and those that monitor the devices regionally (Daubal et al., 2013). This adds to the already tenuous capabilities to get and keep the employment you need to pay for your EM devices.

This creates a huge burden on newly released people, adding to the stresses and worries of looking for employment, housing, and attempting to knit back together families torn over having their loved ones incarcerated. Also, there are fees for Parole Supervision, which are the responsibility of the parolee to pay. Add in the factors of substance abuse and negotiating those stressors and you can see how parole adds another layer of a burden for individuals newly released from prison. With the difficulty in obtaining gainful employment with a felony record, the ability to pay these GPS monitoring fees and parole supervision is truly a hardship. Many people on parole end up not paying the GPS fees, which, of course, add to the risk of parole violation and the prospect of being considered a re-offender and going back to State prison. There is that revolving door again.

The rise in the use of electronic monitoring (EM) began in earnest some years ago, when there was a determined shift from rehabilitation being the primary goal of prisons, to more of a punishment model (Dore et al., 2020). The first relevant feature of mass incarceration is the abandonment of rehabilitation as a central goal of criminal justice. Punishment has become the dominant paradigm. Logan and Gaes (1993), then of the Federal Bureau of Prisons, neatly summarized the official justification of this ideological shift in a 1993 report:

[We note that] punishment is preferable to rehabilitation as an aim of criminal justice and, in particular, that punishment through confinement is the most appropriate mission for a prison. Meta-analysis of research on rehabilitation has not yet established that any particular method of 
treatment is significantly and reliably effective. We still do not know what "works" in correctional treatment, but it really wouldn't matter even if we knew, because the fundamental purpose of imprisonment is not the correction but the punishment of criminal behavior.

A key aspect of this demise of rehabilitation has been the transformation of parole and probation. Control and punishment have replaced counseling and support as the core business of post-release policy (Wacquant, 2009a, $2009 \mathrm{~b}$ ). Much of the rise in recidivism is not a result of a rise in crime, but, rather, new categories of violations that make it so much easier to violate a person's conditions of parole or probation (Bobo and Thompson, 2010; Grubb, 2020). The use of EM or GPS tracking devices is part and parcel of this system of punishment, or control and will always remain, not only a physical but also, a financial barrier to reintegrating back into the community after a period of incarceration/supervision.

\section{RECOMMENDATIONS}

It is clear that the challenges faced by previously incarcerated people; in this case, white males, have strong similarities (although not the same), regardless of geographical location. The similarities identified have allowed for a set of recommendations to be developed. These recommendations are across both the USA and Australia unless explicitly indicated. These recommendations are:

1. Education support fund for allocation to previously incarcerated people to help access education, post-release.

2. Review the practices of insurance and credit companies when dealing with previously incarcerated people.

3. The deletion of media articles outlining people's offences, when/ if their charges become 'spent' or period of incarceration has been completed.

4. Eliminate criminal background checks from Rental Agreements. They are not necessary and are merely a cleverly veiled mechanism to feed biases and stigmas.

5. Eliminate criminal background checks from employment screenings for positions that realistically should not require a record check. 
6. Encourage and empower those with lived experiences to apply them vocationally, allowing others to directly benefit from those experiences. Do not merely outlaw using those experiences against them but elevate them in the hiring criteria for certain positions/ industries.

7. Review the use and costing options behind GPS, electronic monitoring bracelets.

8. Review the implication and use of financial penalties for offenders and their families.

9. Promote and further develop employment networks for previously incarcerated people.

\section{CONCLUSION}

The authors of this piece have reviewed their time being incarcerated in the USA and Australia. Their lived experiences allowed issues of housing, education, employment, fines, and restitution issues, post incarceration to be explored. The experiences of the authors are their own and it must be acknowledged that the experiences of all incarcerated people vary depending upon numerous variables such as terms of imprisonment, jurisdiction where incarceration occurs, offences committed, levels of education and ethnicity.

Increasingly, the thousands of men and women that we share this experience with around the world are people of color. It must be acknowledged that Indigenous Australians and African Americans are two of the most over-represented groups in incarceration and the three authors do not represent those minorities. Their trials and tribulations are significantly impacted by their skin color and ethnic backgrounds. Their revolving door is well oiled and robust and is the topic of many ongoing pieces of scholarly work.

The way forward may also vary for each individual, but it is hoped by the writers that the ethnographic sharing of the similarities between those in the USA and Australia may make the journey easier for someone in the future. The development of future pieces involving minorities, females, other countries and a wider spread of ages of participants has been planned and will provide further context and detail into the issues being faced. 


\section{REFERENCES}

Australian Bureau of Statistics [ABS] (2020) Report on Government Services 2020 - Corrective Services. Retrieved from: https://www.pc.gov.au/research/ongoing/ report-on-government-services/2020/justice/corrective-services

Australian Bureau of Statistics [ABS] (2018a) Media Release: Prisoner Numbers up 4 percent from 2017.

Australian Bureau of Statistics [ABS] (2018b) Prisoners in Australia.

Albright, Shelley and Furjen Denq (1996) "Employer Attitudes toward Hiring Exoffenders", The Prison Journal, 76(2): 118-137.

Austin, James and Patricia Hardyman (2004) "The Risks and Needs of the Returning Prisoner Population", Review of Policy Research, 21(1): 13-29.

Bar-Gill, Oren and Elizabeth Warren (2008) "Making Credit Safer", U. Pa. L. Rev., 157: 1 .

Bartels, Lorana and Marietta Martinovic (2017) "Electronic Monitoring: The Experience in Australia", European Journal of Probation, 9(1): 80-102.

Berger, Todd, Joseph DaGrossa, Adam Matz, Bitna Kim, Anna Macklin, Lily Gleicher, Sarah Manchak, Francis Cullen, Spurgeon Kennedy and Laura House (2013) "This Issue In Brief", Federal Probation, 77(1): 1.

Binswanger, Ingrid, Patrick Krueger and James Steiner (2009) "Prevalence of Chronic Medical Conditions Among Jail and Prison Inmates in the USA Compared with the General Population", Journal of Epidemiology \& Community Health, 63(11): 912-919.

Blumstein, Alfred and Kiminori Nakamura (2009) "Redemption in the Presence of Widespread Criminal Background Checks", Criminology, 47(2): 327-359.

Bobo, Lawrence and Victor Thompson (2010) "Racialized Mass Incarceration: Poverty, Prejudice, and Punishment", Doing Race, 21: 322-355.

Brown, Christian (2015) "Returns to Postincarceration Education for Former Prisoners", Social Science Quarterly, 96(1): 161-175.

Bruns, Angela (2020) "Partner Incarceration and Financial Support from Kin", Journal of Family Issues, 41(11): 2112-2135.

Bushway, Shawn, Michael Stoll and David Weiman (2007) Barriers to Reentry? The Labor Market for Released Prisoners in Post-industrial America, New York: Russell Sage Foundation.

Byrne, James, Arthur Lurigio and Joan Petersilia (1992) Smart Sentencing: The Emergence of Intermediate Sanctions, Newbury Park (CA): Sage.

Byron, William (1970) "Needed: A Special Employment Clearinghouse for Exoffenders", Federal Probation, 34: 53.

Causey, Alexis (2013) "Reviving the Carefully Limited Exception: From Jail to GPS Bail”, Faulkner L. Rev., 5: 59.

Cherney, Adrian and Robin Fitzgerald (2016) "Finding and Keeping a Job: The Value and Meaning of Employment for Parolees", International Journal of Offender Therapy and Comparative Criminology, 60(1): 21-37.

Christians, Clifford, Shakuntala Rao, Stephen Ward and Herman Wasserman (2008) "Toward a Global Media Ethics: Theoretical Perspectives", Ecquid Novi, 29(2): 135-172. 
Cohn, Amanda, Rosslyn O'Connor, Kari Lancaster, Patrick Rawstorn and Sally Nathan (2020) "Media and Political Framing of Crystal Methamphetamine Use in Australia", Drugs: Education, Prevention and Policy, 27(4): 261-270.

Conroy, Niall, Victoria Rubin and Yimin Chen (2015) “Automatic Deception Detection: Methods for Finding Fake News", Proceedings of the Association for Information Science and Technology, 52(1): 1-4.

Cook, Bree, Fiona David and Anna Grant (1999) Victims' Needs, Victims' Rights: Policies and Programs for Victims of Crime in Australia, Canberra: Australian Institute of Criminology.

Coupland, Richard and Mark Olver (2020) "Assessing Protective Factors in Treated Violent Offenders: Associations with Recidivism Reduction and Positive Community Outcomes", Psychological Assessment, 32(5): 493-508.

Craigie, Terry-Ann (2020) "Ban the Box, Convictions, and Public Employment", Economic Inquiry, 58(1): 425-445.

Daly, Mariah (2020) "Boxed Into a Corner: The Fight to Ban Employers from Boxing out Deserving Job Applicants on the Basis of Criminal Record", Drug Enforcement and Policy Center, 20.

Daubal, Mohammed, Olajumoke Fajinmi, Lars Jangaard, Niko Simonson, Brett Yasutake, Joe Newell and Mohamed Ali (2013) "Safe Step: A Real-time GPS Tracking and Analysis System for Criminal Activities Using Ankle Bracelets", presentation at the $21^{\text {st }}$ ACM SIGSPATIAL International Conference on Advances in Geographic Information Systems.

Deuze, Mark (2017) "Understanding Journalism as Newswork: How it Changes, and How it Remains the Same", Westminster Papers in Communication \& Culture, 5(2): 4-24.

Doleac, Jennifer (2019) Empirical Evidence on the Effects of Ban the Box Policies: The State of the Literature in 2019, testimony prepared for the US House Committee on Oversight and Government Reform.

Doleac, Jennifer and Benjamin Hansen (2020) "The Unintended Consequences of "Ban the Box": Statistical Discrimination and Employment Outcomes When Criminal Histories are Hidden", Journal of Labor Economics, 38(2): 321-374.

Dore, Kerry, Malene Hansen, Amy Klegarth, Claudia Fichtel, Flavia Koch, Andrea Springer, Peter Kappeler, Joyce Parga, Tatyana Humle and Christelle Colin (2020) "Review of GPS Collar Deployments and Performance on Nonhuman Primates", Primates, 61(3): 373-387.

Ervin, Laurie and Anne Schneider (1990) "Explaining the Effects of Restitution on Offenders: Results from a National Experiment in Juvenile Courts", in Burt Galaway and Joe Hudson (eds.), Criminal Justice, Restitution, and Reconciliation, Willow Tree Press, pp. 183-206.

Evans, Douglas, Kwan-Lamar Blount-Hill and Michelle Cubellis (2019) "Examining Housing Discrimination Across Race, Gender and Felony History", Housing Studies, 34(5): 761-778.

Fahey, Jennifer, Cheryl Roberts and Len Engel (2006) Employment of Ex-offenders: Employer Perspectives, Boston: Crime and Justice Institute.

Flake, Dallan (2015) "When Any Sentence is a Life Sentence: Employment Discrimination Against Ex-offenders", Wash. UL Rev., 93(1): 45. 
Fletcher, Del (2001) "Ex-Offenders, the Labour Market and the New Public Administration", Public administration, 79(4): 871-891.

Freeman, Richard (2003) Can We Close the Revolving Door? Recidivism vs. Employment of Ex-offenders in the US, Washington (DC): Urban Institute.

Galeshi, Roofia and Riane Bolin (2019) "The Influence of Correctional Education, Skill Proficiency, and Lifelong Learning on Social Outcomes of Incarcerated Undividuals: Results from PIAAC", The Social Science Journal, DOI: 10.1016/j. soscij.2019.09.007

Glaze, Lauren and Thomas Bonczar (2011) Probation and Parole in the United States, 2010, Washington (DC): US Department of Justice, Office of Justice Programs, Bureau of Justice Statistics.

Gordon, Aaron, John Kittross, Michael Dorsher, John Merrill and William Babcock (2011) Controversies in Media Ethics, London: Routledge.

Goulding, Dot and David Brown (2007) Recapturing Freedom: Issues Relating to the Release of Long-term Prisoners into the Community, Toronto: Hawkins Press.

Grier, Annie and Vanessa Bright (2019) "Beyond Jobs: Building Financial Capability for Adults Returning to the Community After Prison", in Christine Callahan, Jodi Jacobson Frey and Rachel Imboden (eds.), Handbook on Financial Social Work: Direct Practice with Vulnerable Populations, London: Routledge.

Griffith, Daiana (2019) Punishment Beyond Prison: Denying Housing to Formerly Incarcerated People in Greater Boston, South Hadley (MA): Mount Holyoke College.

Grgić-Hlača, Nina, Elissa Redmiles, Krishna Gummadi and Adrian Weller (2018) "Human Perceptions of Fairness in Algorithmic Decision Making: A Case Study of Criminal Risk Prediction", proceedings of the 2018 World Wide Web Conference.

Grubb, Jonathan (2020) "Who Goes to Prison and Why?", in Laurie A. Gould and John J. Brent (eds.), Handbook on American Prisons, New York: Routledge.

Halushka, John (2020) "The Runaround: Punishment, Welfare, and Poverty Survival after Prison”, Social Problems, 67(2): 233-250.

Hamilton, Leah and Steven Belenko (2019) "Substance Use Disorder Treatment in the Reentry Environment: Service Receipt and Prisoner Community Reintegration", Criminal Justice and Behavior, 46(9): 1295-1318.

Harding, David, Jessica Wyse, Cheyney Dobson and Jeffrey Morenoff (2014) "Making Ends Meet After Prison”, Journal of Policy Analysis and Management, 33(2): 440470.

Harding, David (2003) “Jean Valjean's Dilemma: The Management of Ex-convict Identity in the Search for Employment", Deviant Behavior, 24(6): 571-595.

Harris, Alexes (2016) A Pound of Flesh: Monetary Sanctions as Punishment for the Poor, New York: Russell Sage Foundation.

Harris, Alexes, Heather Evans and Katherine Beckett (2011) "Courtesy Stigma and Monetary Sanctions: Toward a Socio-cultural Theory of Punishment", American Sociological Review, 76(2): 234-264.

Hatami, Parastou (2019) "Housing is a Human Right: Exiting Prison into Homelessness", Ethos: Official Publication of the Law Society of the Australian Capital Territory, 252: 40-46. 
Hester, Rhys (2019) "Prior Record and Recidivism Risk", American Journal of Criminal Justice, 44(3): 353-375.

Hinds, Lyn (2005) "Three Strikes and You're Out in the West: A Study of Newspaper Coverage of Crime Control in Western Australia", Current Issues in Criminal Justice, 17(2): 239-253.

Jacobs, Leah and Aaron Gottlieb (2020) "The Effect of Housing Circumstances on Recidivism: Evidence from a Sample of People on Probation in San Francisco", Criminal Justice and Behavior, 47(9): 1097-1115.

Jensen, Walter, Jr. and William Giegold (1976) "Finding Jobs for Ex-offenders: A Study of Employers'Attitudes", Am. Bus. LJ, 14: 195-222.

Johnson, Wayne (1989) "If Only: The Experience of Elderly Ex-convicts", Journal of Gerontological Social Work, 14(1-2): 191-208.

Jones, Richard (2003) “Ex-con: Managing a Spoiled Identity”, in Stephen C. Richards and Jeffrey I. Ross (eds.), Convict Criminology, Belmont (CA): Wadsworth, pp. 191-208.

Kang-Brown, Jacob, Eital Schattner-Elmaleh and Oliver Hinds (2020) "People in Prison in 2018", Montana, 3(3,761): 1-3.

Kashyap, Anil, Jeremy Stein and David Wilcox (1992) "Monetary Policy and Credit Conditions: Evidence from the Composition of External Finance", American Economic Review, 83(1): 78-98.

Keene, Danya, Alana Rosenberg, Penelope Schlesinger, Monica Guo and Kim Blankenship (2018) "Navigating Limited and Uncertain Access to Subsidized Housing After Prison", Housing Policy Debate, 28(2): 199-214.

Latessa, Edward, Shelley Johnson and Deborah Koetzle 2020) What Works (and Doesn 't) in Reducing Recidivism, London: Routledge.

Leasure, Peter (2019) "Securing Private Housing with a Criminal Record", Journal of Offender Rehabilitation, 58(1): 30-49.

Levesque, Shane (2020) "Closing the Revolving Door: Mental Illness Within the Criminal Justice System", Nova Law Review, 34(3): 711-738.

Link, Nathan, Jeffrey Ward and Richard Stansfield (2019) "Consequences of Mental and Physical Health for Reentry and Recidivism: Toward a Health-based Model of Desistance", Criminology, 57(3): 544-573.

Logan, Charles and Gerald Gaes (1993) "Meta-analysis and the Rehabilitation of Punishment", Justice Quarterly, 10(2): 245-263.

Madoc-Jones, Iolo, Caroline Hughes, Caro Gorden, Sarah Dubberley, Karen Washington-Dyer, Anya Ahmed, Kelly Lockwood and Mark Wilding (2018) "Rethinking Preventing Homelessness Amongst Prison Leavers", European Journal of Probation, 10(3): 215-231.

Malin, Sally (2007) "Housing and Support After Prison", in Rosemary Sheehan, Gill McIvor and Chris Trotter (eds.), What Works with Women Offenders, London: Routledge, pp. 279-299.

Mielitz, Katherine and Catherine Marcum (2020) "A Consideration for Increasing PostRelease Financial Success", American Journal of Criminal Justice, 45(5): 955-969.

Milivojevic, Sanja and Alyce McGovern (2014) "The Death of Jill Meagher: Crime and Punishment on Social Media", International Journal for Crime, Justice and Social Democracy, 3(3): 22-39. 
Mowen, Thomas, John Boman and Kyle Bares (2019) "Is Substance Abuse Treatment Actually 'Treating'? The Effectiveness of Pre- and Post-release Substance Abuse Programming within the Reentry Process", Criminal Justice Studies, 32(4): 371-385.

Nardini, William (1966) "The Impact of Institutionalisation on Youth Correction Offenders", British Journal of Criminology, 6(2): 193-202.

Naylor, Bronwyn (2011) "Criminal Records and Rehabilitation in Australia", European Journal of Probation, 3(1): 79-96.

Pager, Devah (2003) “The Mark of a Criminal Record", American Journal of Sociology, 108(5): 937-975.

Paterson, Moira and Bronwyn Naylor (2011) “Australian Spent Convictions Reform: A Contextual Analysis", UNSWLJ, 34(3): 938-963.

Pogrebin, Mark, Mary West-Smith, Alexandra Walker and Prabha Unnithan (2014) "Employment Isn't Enough: Financial Obstacles Experienced by Ex-prisoners During the Reentry Process", Criminal Justice Review, 39(4): 394-410.

Rao, Shakuntala and Herman Wasserman (2007) "Global Media Ethics Revisited: A Postcolonial Critique", Global Media and Communication, 3(1): 29-50.

Reid, Katie, Paul Flowers and Michael Larkin (2005) "Exploring Lived Experience", Psychologist, 18(1): 20-23.

Renton, Marc (2013) "Getting Out and Falling Back: A Qualitative Analysis of Contemporary Australian Prison Exit Issues", in Michael H. Pearson (ed.), Crime: International Perspectives, Socioeconomic Factors and Psychological Implications, Hauppauge (NY): Nova Science Publishers, pp. 6-23.

Ross, Jeffrey Ian, Stephen C. Richards, Greg Newbold, Richard Jones, Michael Lenza, Daniel Murphy, Richard Hogan and David G. Curry (2011) "Knocking on the Ivory Tower's Door: The Experience of Ex-convicts Applying for Tenure-track University Positions", Journal of Criminal Justice Education, 22(2): 267-285.

Ruback, Barry (2011) "The Abolition of Fines and Fees: Not Proven and Not Compelling", Criminology \& Public Policy, 10(3): 569-581.

Ryan, Nicole, Jeff Ackerman, Justin Ready and Stuart Kinner (2020) "Indigeneity, Prisoner Visitation and Reincarceration in Australia: The Association between Visits in Prison and Reincarceration for Indigenous and Non-Indigenous People", British Journal of Criminology, 60(4): 1056-1079.

Sampson, Robert and Charles Loeffler (2010) "Punishment's Place: The Local Concentration of Mass Incarceration", Daedalus, 139(3): 20-31.

Scheid, Teresa and Eric Wright (2017) A Handbook for the Study of Mental Health: Social Contexts, Theories, and Systems, Cambridge: Cambridge University Press.

Schneider, Anne and Laurie Ervin (1990) "Specific Deterrence, Rational Choice, and Decision Heuristics: Applications in Juvenile Justice", Social Science Quarterly, 71(3): 585-601.

Scott, Kerry (2016) "Corrections and Education: The Relationship between Education and Recidivism", Journal of Intercultural Disciplines, 15: 147-169.

Sharac, Jessica, Paul Mccrone, Sarah Clement and Graham Thornicroft (2010) "The Economic Impact of Mental Health Stigma and Discrimination: A Systematic Review", Epidemiol Psichiatr Soc, 19(3): 223-232.

Sherrard, Ryan (2020) "Ban the Box" Policies and Criminal Recidivism. Retrieved from: https://papers.ssrn.com/sol3/papers.cfm?abstract_id=3515048 
Simes, Jessica (2019) "Place After Prison: Neighborhood Attainment and Attachment During Reentry", Journal of Urban Affairs, 41(4): 443-463.

Sirois, Catherine (2019) "Household Support and Social Integration in the Year After Prison", Sociological Forum, 34(4): 838-860.

Spier, Philip (2002) Reconviction and Reimprisonment Rates for Released Prisoners, Ministry of Justice.

Steurer, Stephen and Linda Smith (2003) Education Reduces Crime: Three-State Recidivism Study, Lanham (MD): Correctional Education Association.

Sumner, Charles and Antony Sutton (1992) "Victims of Crime and the Mass Media", Criminology Australia, 3(3): 2-4.

Sutton, Robert (2010) Good Boss, Bad Boss: How To Be the Best... and Learn from the Worst, Business Plus.

Tiffen, Rodney (2010) "Changes in Australian Newspapers 1956-2006", Journalism Practice, 4(3): 345-359.

Tostlebe, Jennifer (2017) The Debt Prison: The Effect of Court-ordered Monetary Sanctions on Recidivism, MA Thesis, Sociology, Iowa State University.

Uggen, Christopher (2000) "Work as a Turning Point in the Life Course of Criminals: A Duration Model of Age, Employment, and Recidivism", American Sociological Review, 65(4): 529-546.

Van Manen, Max (1990) Researching Lived Experience: Human Science for an Action Sensitive Pedagogy, Albany: SUNY Press.

Wacquant, Loïc (2009a) Prisons of Poverty, Minneapolis: University of Minnesota Press.

Wacquant, Loïc (2009b) Punishing the Poor: The Neoliberal Government of Social Insecurity, Chapel Hill: Duke University Press.

Wacquant, Loïc (2002a) "The Curious Eclipse of Prison Ethnography in the Age of Mass Incarceration", Ethnography, 3(4): 371-397.

Wacquant, Loïc (2002b) "Slavery to Mass Incarceration", New Left Review, 13. Retrieved from: https://newleftreview.org/issues/ii13/articles/loic-wacquant-fromslavery-to-mass-incarceration

Wang, William (2017) “'Liar, liar pants on fire': A New Benchmark Dataset for Fake News Detection", Computation and Language, arXiv:1705.00648.

Western, Bruce, Jeffrey Kling and David Weiman (2001) "The Labor Market Consequences of Incarceration", Crime \& Delinquency, 47(3): 410-427.

Williams, Betsy, Catherine Brooks and Yotam Shmargad (2018) "How Algorithms Discriminate Based on Data They Lack: Challenges, Solutions, and Policy Implications", Journal of Information Policy, 8: 78-115.

Wilson, David and Anne Reuss (2000) Prison(er) Education: Stories of Change and Transformation, Sheffield Gables (UK): Waterside Press.

Wilson, Sean (2019) "Failures of Reintegration and the Return to Prison", in Jason M. Williams and Steven Kniffley (eds.), Black Males and the Criminal Justice System, New York: Routledge, pp. 85-94.

Wright, Scott and Kim Doyle (2019) "The Evolution of Data Journalism: A Case Study of Australia”, Journalism Studies, 20(13): 1811-1827.

Wolfe, Patrick (1999) Settler Colonialism and the Transformation of Anthropology: The Politics and Poetics of an Ethnographic Event, New York: Cassell. 


\section{ABOUT THE AUTHORS}

Dr. Lukas Carey completed his doctorate in education and has worked in the field for most of his career as a coach, teacher, trainer and educator. While filling a role in local government, he was charged with, and convicted of, receiving secret commissions and served time in prison. During and since his incarceration, Lukas developed a strong interest in the role that previously incarcerated people have in the development of policy and procedure in the justice system concerned with education and post-release employment. $\mathrm{He}$ is a strong advocate for the importance of Convict Criminology and lived experience in shaping the direction of these policies and practices. He can be reached by email at Careyss@westnet.com.au or at the following address:

\section{Lukas Carey \\ 44 Minderoo Crescent \\ Golden Bay, Western Australia, 6174}

Adam Grant came to the understanding during his 27-year incarceration that he had a responsibility to his family, community, and even his past. While still in prison he advanced his education, began facilitating groups and classes for the other men in the facility, and set his feet firmly on the path to redemption that would extend beyond the fences. Currently, Adam works as a Peer Recovery Coach where others directly benefit from his lived experience. He lives his life intentionally, as a conscious example and proponent of the value of those with lived experience. These voices, including his own, are needed for a healthier criminal justice system, on both a macro and micro level. Further, he absolutely believes that the emerging field of Convict Criminology is integral to a more effective and humane criminal justice system going forward. He can be reached by email at theirlifematters500@gmail.com or at the following address:

\section{Adam Grant}

6150 W. Michigan Ave.

Apt. L-16

Lansing, Michigan 48917

USA 
Scott Tompkins is a returned citizen, ex-con, convicted felon, or experienced human, depending on your point of view. Twenty-five years of teaching in all levels of public schools was not the training he had in mind for the 18 months he spent in Michigan State Prisons for assault. He spent his time inside teaching, and gaining an understanding of the men he was serving time with. Since returning, Scott is active with the Prison Creative Arts Program of the University of Michigan and with American Civil Liberties Union, sharing his lived experiences and facilitating that process for others. He can be reached by email at lescotto@umich.edu or at the following address:

Scott Tompkins

3133 W. Cheney Rd.

Maple City, Michigan 49664

USA 